\section{Seaside Petunia Susceptibility to Herbicides Used in Dry Bulb Onion}

\author{
Brian J. Schutte ${ }^{1}$, Abdur Rashid ${ }^{1}$, Israel Marquez ${ }^{1}$, \\ Erik A. Lehnhoff ${ }^{1}$, and Leslie L. Beck ${ }^{2}$
}

Additional Index words. Allium cepa, Calibrachoa parviflora, DCPA, dimethenamid-P, dimethyl tetrachloroterephthalate, flumioxazin, oxyfluorfen, pendimethalin, $S$-metolachlor

Summary. Seaside petunia (Calibrachoa parviflora) is a mat-forming plant species that was recently reported in fall-seeded onion (Allium cepa) in the southwestern United States. To initiate development of herbicide recommendations for seaside petunia in onion, we conducted a study to determine seaside petunia susceptibility to commonly used herbicides for broadleaf weed control after onion emergence. Our study included herbicides applied at below-label rates, which provided insights on seaside petunia responses to reductions in the amount of herbicide available for plant absorption. For herbicides with preemergence activity, our growth chamber study indicated that soil applications of flumioxazin or oxyfluorfen ( 0.06 and $0.25 \mathrm{lb} /$ acre, respectively) prevented seaside petunia seedling emergence when applied at $0.125 \times, 0.25 \times, 0.5 \times$, and $1.0 \times$ the labeled rates for onion. Labeled rate treatments of dimethenamid-P $(0.84 \mathrm{lb} /$ acre $)$ and $S$-metolachlor $(0.64 \mathrm{lb} /$ acre $)$ inhibited seedling emergence similar to labeled rate treatments of flumioxazin and oxyfluorfen; however, below-label rate treatments of dimethenamid-P and $S$-metolachlor resulted in diminished control of seaside petunia compared with the labeled rate treatments. Following labeled rate applications of dimethyl tetrachloroterephthalate $[\operatorname{DCPA}(6 \mathrm{lb} / \mathrm{acre})]$ and pendimethalin $(0.71 \mathrm{lb} /$ acre $)$, more than $50 \%$ of seaside petunia seedlings emerged compared with the nontreated control. For herbicides with postemergence activity on weeds, our greenhouse study indicated that bromoxynil at $0.37 \mathrm{lb} /$ acre, flumioxazin at $0.06 \mathrm{lb} /$ acre, and oxyfluorfen at $0.25 \mathrm{lb} /$ acre equally reduced growth of seaside petunia plants that were small at the time of spraying (stem length, $1-2 \mathrm{~cm}$ ). Postemergence control of seaside petunia with oxyfluorfen and flumioxazin decreased as plant size at spraying increased; however, bromoxynil effects on seaside petunia remained high as stem length at spraying increased from 5 to $12 \mathrm{~cm}$. Based on the results of this study, we conclude that promising herbicide programs for seaside petunia in onion include oxyfluorfen or flumioxazin for preemergence control and bromoxynil for postemergence control. These herbicides, alone and in combination, should be evaluated for seaside petunia control and onion phytotoxicity in future field trials.

Received for publication 1 June 2021. Accepted for publication 11 Aug. 2021.

Published online 27 September 2021

${ }^{1}$ Department of Entomology, Plant Pathology and Weed Science, New Mexico State University, 945 College Drive, Las Cruces, NM 88003

${ }^{2}$ Department of Extension Plant Sciences, New Mexico State University, 945 College Drive, Las Cruces, NM 88003

Funding for this project was provided by the New Mexico State University Agricultural Experiment Station.

We gratefully acknowledge the assistance of Ed Morris in collecting soil and seed samples. We thank Geno Picchioni and Joseph Wood for reviewing this manuscript.

Mention of tradenames or commercial products in this article is solely for the purpose of providing specific information and does not imply recommendation or endorsement by New Mexico State University.

B.J.S. is the corresponding author. E-mail: bschutte@nmsu.edu.

This is an open access article distributed under the CC BY-NC-ND license (https://creativecommons. org/licenses/by-nc-nd/4.0/).

https://doi.org/10.21273/HORTTECH04898-21 in nine states, with New Mexico responsible for about half the total nonstorage (herein "onion")] is a vegetable that is cultivated worldwide (Food and Agriculture Organization of the United Nations, 2021). In the United States, onion is grown primarily onion produced during summer (U.S. Department of Agriculture, National Agricultural Statistics Service, 2021e). In New Mexico in $2020, \approx 4.15$ million cwt of onion were harvested from 6200 acres (U.S. Department of Agriculture, National Agricultural Statistics Service, 2021b, 2021c), which provided $\$ 87.2$ million in cash receipts to New Mexico farmers, and made the production value of onion in New Mexico fifth highest among onion-producing states in the country (U.S. Department of Agriculture, National Agricultural Statistics Service, 2021d). Across the United States in 2020 , onion was planted on 134,700 acres, and onion production was worth about $\$ 887$ million (U.S. Department of Agriculture, National Agricultural Statistics Service, 202la, 202ld).

Most of New Mexico's onion production is located in three contiguous counties in the southern region (Doña Ana, Luna, and Sierra Counties). This region features favorable soil (i.e., welldrained sandy-loam to clay-loam soil) and relatively mild winters that allow farmers to plant onion in fall and early spring, irrigate onion as needed, and harvest onion May through July. Onion leaf canopies absorb relatively little of the incoming photosynthetically active radiation (Tei et al., 1996), and thus onion is not competitive against weeds throughout much of the onion growing season (Menges and Tamez, 1981; Wicks et al., 1973; Williams et al., 2007). To reduce the impacts of weeds on onion, New Mexico farmers repeatedly use combinations of herbicides, tillage, and hand weeding to remove weeds from onion fields; however, weeds continue to persist. Weeds that have long been common in onion fields in southern New Mexico include, but are not limited to, sowthistle species (Sonchus sp.), london

\begin{tabular}{llll}
\hline $\begin{array}{l}\text { Units } \\
\begin{array}{l}\text { To convert U.S. to SI, } \\
\text { multiply by }\end{array}\end{array}$ & U.S. unit & SI unit & $\begin{array}{l}\text { To convert SI to U.S., } \\
\text { multiply by }\end{array}$ \\
\hline 0.4047 & acre $(\mathrm{s})$ & $\mathrm{ha}$ & 2.4711 \\
0.0454 & $\mathrm{cwt}$ & $\mathrm{Mg}$ & 22.0462 \\
29.5735 & $\mathrm{fl} \mathrm{oz}$ & $\mathrm{mL}$ & 0.0338 \\
9.3540 & $\mathrm{gal} / \mathrm{acre}$ & $\mathrm{L} \cdot \mathrm{ha}^{-1}$ & 0.1069 \\
2.54 & inch $(\mathrm{es})$ & $\mathrm{cm}$ & 0.3937 \\
25.4 & inch $(\mathrm{es})$ & $\mathrm{mm}$ & 0.0394 \\
0.4536 & $\mathrm{lb}$ & $\mathrm{kg}$ & 2.2046 \\
1.1209 & $\mathrm{lb} / \mathrm{acre}$ & $\mathrm{kg} \cdot \mathrm{ha}^{-1}$ & 0.8922 \\
0.1198 & $\mathrm{lb} / \mathrm{gal}$ & $\mathrm{kg} \cdot \mathrm{L}^{-1}$ & 8.3454 \\
$\left({ }^{\circ} \mathrm{F}-32\right) \div 1.8$ & ${ }^{\circ} \mathrm{F}$ & ${ }^{\circ} \mathrm{C}$ & $\left({ }^{\circ} \mathrm{C} \times 1.8\right)+32$ \\
\hline
\end{tabular}




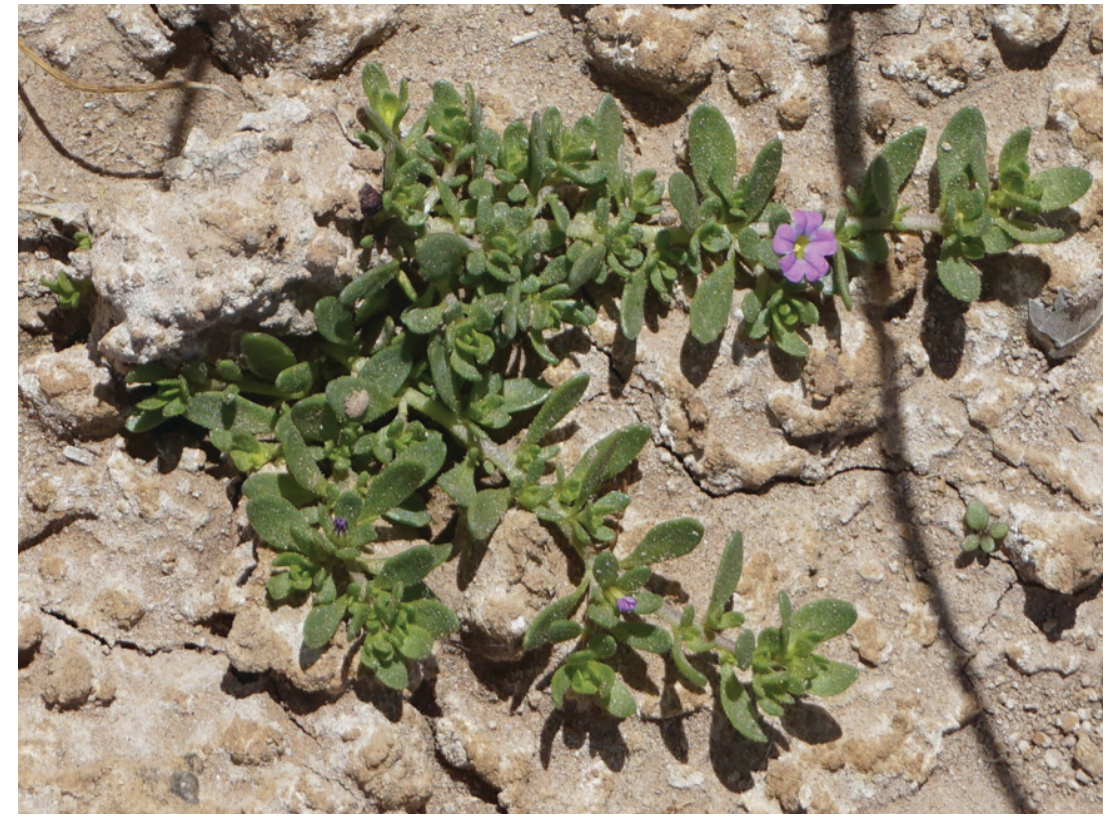

Fig. 1. Seaside petunia plant featuring a purplish, funnel-formed corolla $(5-7 \mathrm{~mm}$ long) and linear to elliptical, nearly sessile leaves $(8-18 \mathrm{~mm}$ long); $1 \mathrm{~mm}=$ 0.0394 inch.

rocket (Sisymbrium irio), flixweed (Descurainia sophia), palmer amaranth (Amaranthus palmeri), wright groundcherry (Physalis acutifolia), purple nutsedge (Cyperus rotundus), and yellow nutsedge (Cyperus esculentus).

Since $\approx 2015$, a weed species in the nightshade family (Solanaceae) seaside petunia [Calibrachoa parviflora (synonym Petunia parviflora)]-has become increasingly abundant in New Mexico onion fields. Seaside petunia (Fig. 1) was historically found in sandy arroyos in the southwestern United States (Abrams, 1951; Wooten and Standley, 1915) and is now verified in 15 states, usually in geomorphic settings where soil is saturated or flooded at least seasonally (U.S. Department of Agriculture, Natural Resources Conservation Service, 2021). Seaside petunia stems are prostrate, diffusely branched, and 2 to $28 \mathrm{~cm}$ long (Beck and Wanstall, 2021). Along the stem, linear to elliptical (8- to 18-mm long) leaves are alternate, sessile, or have very short petioles. Seaside petunia leaves are fleshy and feature glandular hairs. Flowers on short pedicels are located in leaf axils and have a purplish, funnel-formed corolla that is 5 to $7 \mathrm{~mm}$ long. Seeds are spheroidal to angular and are 0.5 to $0.6 \mathrm{~mm}$ in diameter (Gunn and Gaffney, 1974). In New Mexico, seaside petunia has an annual lifecycle, and seedling emergence occurs from January to June.
Seaside petunia infestations that emerge during the middle phases of the growing season for fall-seeded onions can cause substantial losses in onion bulb yield (Schutte and Morris, 2019). This is generally consistent with previous studies that determined onion must be kept weed free for the first 8 to 12 weeks after onion emergence to prevent yield loss (Menges and Tamez, 1981; Wicks et al., 1973). In addition to reducing yields, seaside petunia infestations that emerge during middle phases of the onion growing season need to be controlled because they may interfere with onion harvest operations and possibly contribute to the weed seedbank, creating problems for future crops.

Farmers can potentially use herbicides to control midseason infestations of seaside petunia in onion. However, to our knowledge, there is no information on the abilities of herbicides registered for over-the-top applications in onion to control seaside petunia. Herbicides registered for over-the-top applications in New Mexico onion include the following soil-applied herbicides with activity on broadleaf and grass weeds: DCPA, dimethenamid-P, oxyfluorfen, pendimethalin, $S$-metolachlor, and trifluralin. Postemergence herbicides registered for over-the-top applications in New Mexico onion and active on broadleaf weeds include bromoxynil and oxyfluorfen. Flumioxazin, which has pre- and postemergence activity on broadleaf and some grass weeds, can be applied to onion in some states, but is currently not registered for onion in New Mexico.

The overall objective of this study was to determine seaside petunia susceptibility to herbicides registered for over-the-top applications in onion. For herbicides with preemergence activity on weeds, this study compared preemergence herbicides for their ability to inhibit seedling establishment when applied at different rates. Treatments with rates less than labeled guidelines were not meant to serve as bases for recommendations. Rather, below-label rates were intended to identify preemergence herbicides to which seaside petunia is extremely susceptible. To assess seaside petunia susceptibility to herbicides with postemergence activity on weeds, this study compared postemergence herbicides for their capacity to control seaside petunia at different stages of growth.

\section{Materials and methods}

Seed and soil materials. Seaside petunia seeds were obtained from plants growing in an onion field at the New Mexico State University (NMSU), Leyendecker Plant Science Research Center (lat. $32.19^{\circ} \mathrm{N}$, long. $106.74^{\circ} \mathrm{W}$ ) near Las Cruces during Spring 2017. Seed-bearing seaside petunia plants were hand-clipped at the soil surface and dried in the laboratory at room temperature $\left(20\right.$ to $25^{\circ} \mathrm{C}$ ) for $28 \mathrm{~d}$. Dried plants were then hand-threshed, and seeds were separated from chaff with sequential combinations of sieving and forcedair separation. Cleaned seeds were stored in an airtight container at $4^{\circ} \mathrm{C}$ until needed. Before use in experiments, seed samples were subjected to 14-d germination assays conducted with petri dishes lined with moistened filter papers and placed in a growth chamber set to 27/ $17^{\circ} \mathrm{C}$ day/night, 12-h photoperiods. These conditions were determined to be favorable for germination of seaside petunia (B. Schutte, unpublished data). At the conclusion of the germination assays, nongerminated seeds were tested for viability using the imbibed crush test (Borza et al., 2007). At the beginning of each experiment, at least $84 \%$ of viable seeds could be germinated. 
Soil for the experiments was a loamy sand $(87 \%$ sand, $6 \%$ silt, $7 \%$ clay, $0.3 \%$ organic matter; $\mathrm{pH}, 8.2$ ) collected from a fallow field at the NMSU Agricultural Science Center at Los Lunas (lat. $34.77^{\circ} \mathrm{N}$, long. $106.76^{\circ} \mathrm{W}$ ). The field was not treated with herbicides for at least 2 years before soil was collected. Soil with high sand content was selected because coarse-textured soil is advantageous for onion production (Walker et al., 2009).

Preemergence herbicide StUdy. The study was conducted in a growth chamber and included two experimental runs. Experimental run 1 occurred from 25 Oct. to 24 Nov. 2019. Experimental run 2 occurred from 20 Dec. 2019 to 21 Jan. 2020.

Experimental units were plastic pots $(8 \mathrm{~cm}$ wide, $8 \mathrm{~cm}$ long, $8 \mathrm{~cm}$ deep) filled with the loamy sand soil described previously. Pot bottoms included drainage holes that were lined with nylon fabric mesh $(<0.1-\mathrm{mm}$ opening) that prevented soil loss during filling. Each pot contained 200 seaside petunia seeds distributed across the soil surface and buried at $0.5 \mathrm{~cm}$.

Treatments were factorial combinations of herbicide and rate. Herbicides included DCPA [6 lb/gal, flowable formulation (Dacthal Flowable; Amvac Chemical Corp., Los Angeles, CA)], dimethenamid-P $[6 \mathrm{lb} / \mathrm{gal}$, emulsifiable concentrate (Outlook; BASF Corp., Research Triangle Park, NC)], flumioxazin $[0.51 \mathrm{lb} / \mathrm{lb}$, water-dispersible granule (Chateau SW; Valent U.S.A. Corp., Walnut Creek, CA)], oxyfluorfen [4 lb/ gal, suspension concentrate (Goaltender; Corteva Agriscience, Indianapolis, IN)], pendimethalin $[3.8 \mathrm{lb} / \mathrm{gal}$, capsule suspension (Prowl $\mathrm{H}_{2} \mathrm{O}$, BASF Corp.)], and $S$-metolachlor $[7.62 \mathrm{lb} /$ gal, emulsifiable concentrate (Dual Magnum; Syngenta Crop Protection, Greensboro, $\mathrm{NC})$ ]. Herbicide rates were $0 \times$ (nontreated control), $0.125 \times, 0.25 \times, 0.5 \times$, and $1.0 \times$ the labeled rates for onion on coarse soil. Labeled rates were as follows: DCPA at $6 \mathrm{lb} /$ acre, dimethenamid-P at $0.84 \mathrm{lb} /$ acre, flumioxazin at $0.06 \mathrm{lb} /$ acre, oxyfluorfen at $0.25 \mathrm{lb} /$ acre, pendimethalin at $0.7 \mathrm{l} \mathrm{lb} /$ acre, and $S$-metolachlor at $0.64 \mathrm{lb} /$ acre. Herbicides were applied using a moving-nozzle spray chamber (DeVries Manufacturing, Hollendale, MN) equipped with an even-flat nozzle tip (8002EVS; TeeJet Technologies, Wheaton, IL) and calibrated to deliver $20 \mathrm{gal} /$ acre. After application, herbicides were incorporated by applying 75 $\mathrm{mL}$ of water per pot over $5 \mathrm{~min}$.

After the initial irrigation, pots were transferred to growth chambers set to $27 / 17^{\circ} \mathrm{C}$ day/night, 12 -h photoperiods. Treatments were arranged on growth chamber shelves in a randomized complete block design with four replications. Once in growth chambers, pots were watered every $2 \mathrm{~d}$ by adding $30 \mathrm{~mL}$ water to the soil surface in each pot. This irrigation procedure did not cause water to exit through holes in the bottoms of pots. Seaside petunia seedlings were counted at $30 \mathrm{~d}$ after herbicide treatment (DAT).

PostemergenCe herbiCIDE STUdy. A study was conducted in a greenhouse located at the NMSU Leyendecker Plant Science Research Center. The study consisted of two experimental runs. Experimental run 1 occurred from 13 May to 20 Aug. 2018. Experimental run 2 occurred from 3 Sept. to 18 Dec. 2018. Throughout the study, air temperature in the greenhouse ranged from 18 to $35^{\circ} \mathrm{C}$. On days for which the duration of natural daylight was less than $12 \mathrm{~h}$, natural light was supplemented with light from high-pressure sodium lamps (P.L. Light Systems, Beamsville, Ontario, Canada) from 6:00 to 8:00 AM and 5:00 to 8:00 PM.

Experimental units were square plastic pots that were $9 \times 9 \mathrm{~cm}$ wide, and $9 \mathrm{~cm}$ deep. Pot bottoms included drainage holes that were lined with nylon fabric mesh $(<0.1-\mathrm{mm}$ opening) that prevented soil loss during filling. About 40 seaside petunia seeds were planted at a depth of $0.5 \mathrm{~cm}$ in each pot and later thinned to one plant per pot at $14 \mathrm{~d}$ after seedling emergence. Before thinning, pots were subirrigated by placement in basins with water. After seaside petunia populations were thinned, pots were surface irrigated with a sprinkler canister as required.

Treatments were factorial combinations of postemergence herbicide and seaside petunia plant size at spraying. Herbicide treatments were 1) bromoxynil at $0.37 \mathrm{lb} /$ acre $[2 \mathrm{lb} /$ gal, emulsifiable concentrate (Moxy 2E; Winfield Solutions, St. Paul, $\mathrm{MN})$, 2) flumioxazin at $0.06 \mathrm{lb} /$ acre (Chateau SW), 3) oxyfluorfen at 0.25 $\mathrm{lb} /$ acre (Goaltender) with $0.25 \% \mathrm{v} / \mathrm{v}$ nonionic surfactant (Induce; Helena Chemical Co., Collierville, TN), and 4) no herbicide (nontreated control for comparison). Herbicide rates were maximum labeled rates for single applications in onion in New Mexico. Herbicides were applied using a moving-nozzle spray chamber (DeVries Manufacturing) equipped with an even-flat nozzle tip (8002EVS, TeeJet Technologies). Spray application rates were the equivalent of $20 \mathrm{gal} / \mathrm{acre}$ for flumioxazin and oxyfluorfen, and $\mathbf{5 0}$ gal/acre for bromoxynil. Spray application rates were minimum spray volumes for emerged onion according to labeled guidelines (Dow AgroScience, 2014; Valent U.S.A., 2019; Winfield Solutions, 2016). To ensure herbicide absorption by seaside petunia plants, pots were not watered for $48 \mathrm{~h}$ after herbicide application.

At the time of spray, seaside petunia plants had one primary stem. The length of the primary stem was the basis for plant size treatments. Seaside petunia size treatments were 1) stem length 1 to $2 \mathrm{~cm}, 2$ ) stem length 5 to $7 \mathrm{~cm}, 3$ ) stem length 8 to $12 \mathrm{~cm}$, and 4) stem length 13 to $16 \mathrm{~cm}$. Seaside petunia size treatments were obtained by initiating new experimental units every $16 \mathrm{~d}$ for $64 \mathrm{~d}$. Specifically, plants with stems 13 to $16 \mathrm{~cm}$ were sown 64 $\mathrm{d}$ before spraying, plants with stems 8 to $12 \mathrm{~cm}$ were sown $48 \mathrm{~d}$ before spraying, plants with stems 5 to $7 \mathrm{~cm}$ were sown $32 \mathrm{~d}$ before spraying, and plants with stems 1 to $2 \mathrm{~cm}$ were sown $16 \mathrm{~d}$ before spraying. This sowing schedule allowed all seaside petunia plants to be treated with herbicides on the same day.

Immediately after spraying, pots were arranged on the greenhouse bench in a randomized complete block design with four replications. At 14 DAT, seaside petunia plants were evaluated for visual estimates of herbicide injury using a rating scale, with 0.5 intervals, ranging from 0 to 10 , with 0 indicating no visual difference from nontreated control and 10 indicating complete shoot death. At 14 DAT, seaside petunia plants were harvested and weighed immediately to determine aboveground fresh biomass.

Data Analysis. Statistical analyses were performed using the open source statistical software program $\mathrm{R}$ (version 3.6.2; R Foundation for Statistical Computing, Vienna, Austria). Levene's test for homogeneity of variances (Zar, 1999) indicated equal variances between experimental runs, and 
preliminary analyses indicated that response variables were unaffected by experimental run or interactions between treatments and runs $(P>$ $0.05)$. Therefore, data for the two experimental runs were combined.

For the preemergence herbicide study, seaside petunia seedling density data were expressed as percentages of the nontreated control and were analyzed with a two-step process. First, seaside petunia percent density responses to preemergence herbicides at the $1.0 \times$ labeled rates were assessed with a linear mixed-effect model developed with the $\mathrm{R}$ library nlme. The fixed effects were herbicide and run, and the random effect was replicate within run. During model development, visual inspections of residuals plotted against fitted values indicated that the arcsine transformation of the response variable improved model fit. Thus, percentage data for seaside petunia density were subjected to arcsine transformations before final statistical modeling. For presentation in this article, arcsine-transformed data were back-transformed after statistical analyses.

Preemergence herbicides with equally low numbers of seaside petunia seedlings were assessed further with the second step for analyzing seaside petunia seedling density data. In the second step, mean densities for a specific herbicide were expressed as percentages of nontreated controls and plotted as functions of application rate. Then, the R library drc was used to select the best-fit, nonlinear regression model from the following four candidates: 1) three-parameter log-logistic model, 2) three-parameter exponential decay model, 3) three-parameter Weibull type I model, and 4) three-parameter Weibull type II model (Ritz et al., 2015). To account for inherent constraints on the relationship between percent seedling density and herbicide application rate, upper asymptotes were restricted to values less than or equal to 100 , and lower asymptotes were restricted to values greater than or equal to zero. Model fits were evaluated with information criteria provided by the $d r c$ function mselect, with best-fit models featuring minimum values for Akaike's information criterion. Best-fit models were used to compare descriptively preemergence herbicides at below-label rates. However, best-fit models were not used to determine effective doses based on relative distances between upper and lower asymptotes (i.e., $\mathrm{ED}_{50}$ ), because lower asymptotes were substantially greater than zero for some preemergence herbicides.

For the postemergence herbicide study, visual injury rating data were analyzed with Friedman's test followed by post hoc Conover tests for non parametric data using the $\mathrm{R}$ library PMCMRplus. The $\mathrm{R}$ library nlme was used to develop a linear mixed-effects model for the effects of plant size at spraying and herbicide on seaside petunia biomass at 14 DAT. In this model, the response variable was the arcsine transformation of seaside petunia biomass expressed as a percentage of the control treatment. Visual inspections of residuals plotted against fitted values indicated that the arcsine transformation of the response variable improved model fit. Arcsine-transformed data were back-transformed for presentation in this article. Fixed effects in the model were combinations of plant size at spraying, herbicide, and run. The random effect was replicate in run. After development of the linear mixedeffects model, the R library multcomp

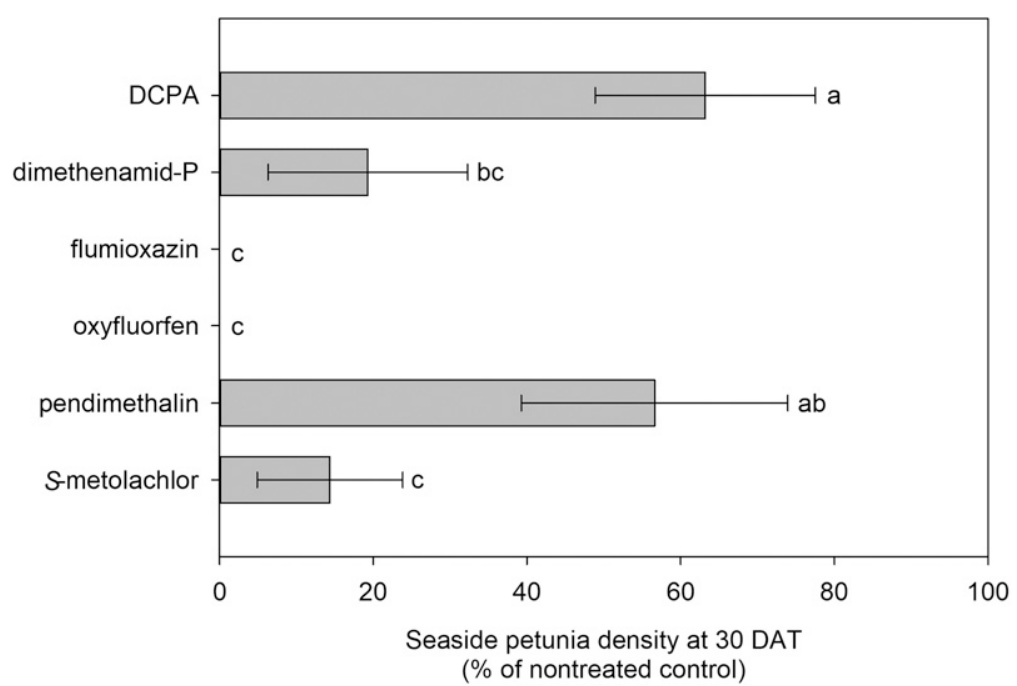

Fig. 2. Seaside petunia emergence responses to dimethyl tetrachloroterephthalate (DCPA), dimethenamid-P, flumioxazin, pendimethalin, and $S$-metolachlor applied to soil at labeled rates for onion on coarse soil. Labeled rates were DCPA at $6 \mathrm{lb} /$ acre, dimethenamid-P at $0.84 \mathrm{lb} /$ acre, flumioxazin at $0.06 \mathrm{lb} / \mathrm{acre}$, oxyfluorfen at $0.25 \mathrm{lb} /$ acre, pendimethalin at $0.71 \mathrm{lb} /$ acre, and $S$-metolachlor at $0.64 \mathrm{lb} / \mathrm{acre}$. Herbicide effects on seedling emergence were determined at $30 \mathrm{~d}$ after treatment (DAT). The study was performed in growth chambers set to $27 /$ $17^{\circ} \mathrm{C}\left(80.6 / 62.6^{\circ} \mathrm{F}\right)$ day/night, 12 -h photoperiods. Bars are means ( $\left.\pm \mathrm{SE}\right)$ of eight replications from two pooled experimental runs. Means that share the same letter are not different at $P<0.05$ according to Tukey's test performed following arcsine transformation of the response variable. Data were back-transformed for presentation in this figure; $1 \mathrm{lb} /$ acre $=1.1209 \mathrm{~kg} \cdot \mathrm{ha}^{-1}$. 
Table 1. Best-fit models for herbicide application rate effects on seaside petunia seedling densities expressed as percentages of nontreated controls.

\begin{tabular}{|c|c|c|c|c|c|c|}
\hline Herbicide & Best-fit model & Model formula & Model parameter & Estimate & SE & $P$ value \\
\hline \multirow[t]{3}{*}{ Dimethenamid-P } & Exponential decay & $y=a+(b-a) \times \exp \left(\frac{-x}{c}\right)$ & $a^{\mathrm{z}}$ & 18.39 & 2.95 & 0.02 \\
\hline & & & $b^{\mathrm{y}}$ & 100 & $-^{\mathrm{u}}$ & - \\
\hline & & & $c^{\mathrm{x}}$ & 0.16 & 0.01 & 0.008 \\
\hline \multirow[t]{3}{*}{ Flumioxazin } & Weibull, type 1 & $y=d \times \exp (-\exp (e(\log (x)-\log (f))))$ & $e^{\mathrm{w}}$ & 4.15 & $5.44 \times 10^{-5}$ & $<0.001$ \\
\hline & & & $d^{y}$ & 2.46 & $7.54 \times 10^{-6}$ & $<0.001$ \\
\hline & & & $f^{\mathrm{v}}$ & 0.41 & $1.34 \times 10^{-6}$ & $<0.001$ \\
\hline & & & $f^{v}$ & 0.25 & $3.49 \times 10^{-6}$ & $<0.001$ \\
\hline \multirow[t]{3}{*}{$S$-metolachlor } & Exponential decay & $y=a+(b-a) \times \exp \left(\frac{-x}{c}\right)$ & $a^{\mathrm{z}}$ & 14.712 & 0.61 & 0.03 \\
\hline & & & $b^{\mathrm{y}}$ & 85.54 & 6.86 & 0.05 \\
\hline & & & $c^{\mathrm{x}}$ & 0.13 & 0.01 & 0.05 \\
\hline
\end{tabular}

${ }^{\mathrm{z}}$ Lower asymptote.

${ }^{\mathrm{y}}$ Upper asymptote.

${ }^{\mathrm{x}}$ Steepness of decay

${ }^{\mathrm{w}}$ Slope at inflection point.

${ }^{v} x$-Value midway between upper and lower limits.

${ }^{u}$ Upper asymptote was constrained to 100 ; thus, sE and $P$ value could not be calculated.

Herbicides were applied at $0.125 \times, 0.25 \times, 0.5 \times$, and $1.0 \times$ labeled rates for onion. Labeled rates were $0.84 \mathrm{lb} / \mathrm{acre}$ for dimethenamid-P, $0.06 \mathrm{lb} / \mathrm{acre}$ for flumioxazin, $0.25 \mathrm{lb} /$ acre for oxyfluorfen, and $0.64 \mathrm{lb} /$ acre for $S$-metolachlor $\left(1 \mathrm{lb} / \mathrm{acre}=1.1209 \mathrm{~kg} \cdot \mathrm{ha}^{-1}\right)$. Graphical representations of models with data are presented in Fig. 3 .

labeled rate (Fig. 3). Similar to dimethenamid-P, $S$-metolachlor control of seaside petunia decreased sharply as application rates decreased from $1.0 \times$, with percent seeding density reaching $41 \%$ of the nontreated control at the $0.125 \times$ labeled rate. For oxyfluorfen and flumioxazin, best-fit nonlinear models indicated that seaside petunia seedling density, expressed as percentages of nontreated controls, was less than 3\% at all application rates.

Postemergence herbicide STUdy. Bromoxynil, oxyfluorfen, and flumioxazin equally reduced growth of seaside petunia plants that were small at the time of spraying (stem length, $1-2 \mathrm{~cm}$ ) (Fig. 4A). For seaside petunia plants with stems measuring 5 to $16 \mathrm{~cm}$, bromoxynil caused greater reductions in growth than oxyfluorfen. Bromoxynil was similarly effective on seaside petunia plants with stems measuring 1 to 12 $\mathrm{cm}$, whereas oxyfluorfen was less effective on larger plants. For seaside petunia plants with stems measuring 8 to 12 $\mathrm{cm}$, biomass was $4.8 \%$ of the nontreated control after the bromoxynil treatment; but, after the oxyfluorfen treatment, biomass for these plants was $53.1 \%$ of the nontreated control. Flumioxazin reduced growth of seaside petunia plants with stems measuring 5 to $7 \mathrm{~cm}$ to a similar degree as bromoxynil and oxyfluorfen; but, for seaside petunia plants with stems measuring 8 to $12 \mathrm{~cm}$, flumioxazin caused greater reductions in biomass than oxyfluorfen. For seaside petunia plants with stems measuring 13 to $16 \mathrm{~cm}$, bromoxynil and flumioxazin caused greater reductions in aboveground biomass than oxyfluorfen.

Herbicide-induced reductions in seaside petunia biomass coincided with visible symptoms of herbicide injury, including necrotic spotting to complete shoot death. For small seaside petunia plants, visual estimates of control at 14 DAT were high and similar among the different herbicides (Fig. 4B). As plant size at spraying increased, visual estimates of control decreased for oxyfluorfen, but remained high for bromoxynil and flumioxazin. For seaside petunia plants with stems measuring 8 to $16 \mathrm{~cm}$, visual estimates for bromoxynil and flumioxazin were greater than visual estimates of control for oxyfluorfen.

\section{Discussion}

This study was conducted to initiate development of herbicide recommendations for seaside petunia in onion in New Mexico. Herbicide recommendations based only on results from controlled-environment studies are unreliable because herbicide efficacy in the field is influenced by the environment before, during, and after spraying (Kudsk and Kristensen, 1992). Therefore, herbicide recommendations are generally developed from field trials that determine herbicide efficacies across a range of conditions within a defined climatic area (Ekeleme et al., 2020). Such field trials are more efficient when they focus on herbicides to which targeted weeds are highly susceptible. Accordingly, the results of this study can streamline field trials for clarifying chemical strategies for controlling seaside petunia in onion.

Among the six herbicides evaluated for preemergence control, seaside petunia was most susceptible to oxyfluorfen and flumioxazin. This was consistent with previous studies that indicated oxyfluorfen or flumioxazin provided more control of selected broadleaf annual weeds than pendimethalin, $S$-metolachlor, or dimethenamid-P. For example, Richardson and Zandstra (2006) determined that flumioxazin provided greater control of common ragweed (Ambrosia artemisiifolia) than pendimethalin or $S$-metolachlor. Taylor-Lovell et al. (2002) observed that control of velvetleaf (Abutilon theophasti), common cocklebur (Xanthium strumarium), and ivyleaf morningglory (Ipomoea bederacea) was greater with flumioxazin than pendimethalin. When compared against dimethenamid-P, Grichar et al. (2002) determined that flumioxazin provided greater control of citronmelon (Citrullus lanatus var. citroides), and Khamare et al. (2020) determined that flumioxazin provided greater control of pra xelis (Praxelis clematidea). Eclipta (Eclipta prostrata) was better controlled by oxyfluorfen than pendimethalin (Gilreath et al., 2008), and oxyfluorfen gave the best preemergence control of weeds at a site 


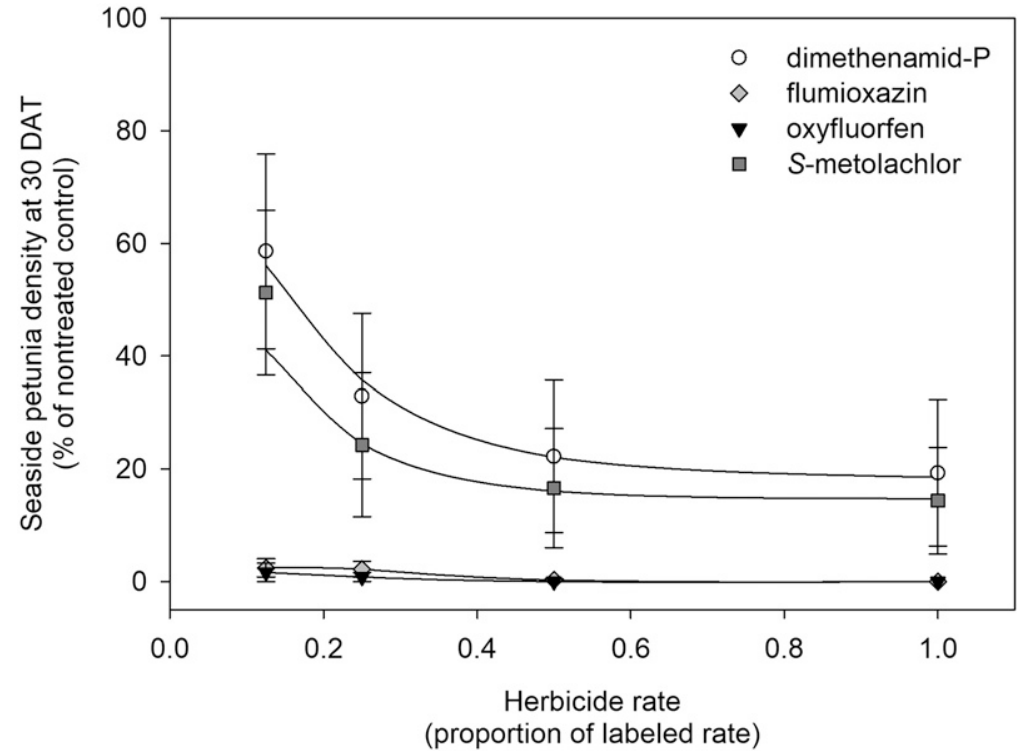

Fig. 3. Seaside petunia emergence responses to dimethenamid-P, flumioxazin, oxyfluorfen, and $S$-metolachlor applied at proportions of labeled rates for onion on coarse soil. Labeled rates were dimethenamid-P at $0.84 \mathrm{lb} / \mathrm{acre}$, flumioxazin at $0.06 \mathrm{lb} /$ acre, oxyfluorfen at $0.25 \mathrm{lb} /$ acre, and $S$-metolachlor at $0.64 \mathrm{lb} /$ acre. Herbicide effects on seedling emergence were determined at $30 \mathrm{~d}$ after treatment (DAT). The study was performed in growth chambers set to $27 / 17^{\circ} \mathrm{C}(80.6 /$ $\left.62.6^{\circ} \mathrm{F}\right) \mathrm{day} /$ night, 12 -h photoperiods. Data points are means $( \pm \mathrm{SE})$ of eight replications from two pooled experimental runs. Regression equations can be found in Table $1 ; 1 \mathrm{lb} /$ acre $=1.1209 \mathrm{~kg} \cdot \mathrm{ha}^{-1}$.

where the most common weed was nettleleaf goosefoot (Chenopodium murale) (Qasem, 2007). Broadleaf weed control outcomes for pendimethalin, $S$-metolachlor, and dimethenamid-P can be improved with additional herbicides in the spray solution (Grichar, 2007; Hutchinson, 2012); however, some tank mixtures may increase risk of onion injury compared with herbicides applied alone (Herrmann et al., 2017).

Oxyfluorfen and flumioxazin are broad-spectrum, diphenyl-ether herbicides that inhibit protoporphyrinogen oxidase, an enzyme that catalyzes the biosynthesis of chlorophyll and heme compounds in plants (Zhao et al., 2020). The results of our study suggest that seaside petunia is especially susceptible to preemergence herbicides that interfere with protoporphyrinogen oxidase activity. Oxyfluorfen is registered for over-the-top applications in onions that have at least two true leaves, or at least one true leaf in states with a specific Special Local Needs label (Dow AgroScience, 2014). In only Michigan, New York, North Dakota, and Wisconsin, flumioxazin can be applied to transplanted onions with two to six leaves, and directseeded onions with three to six leaves
(Valent U.S.A., 2019). The onion growth stages at which flumioxazin and oxyfluorfen can be applied coincide with seaside petunia emergence, and thus, flumioxazin and oxyfluorfen are candidate herbicides for preemergence control of seaside petunia in onion.

Onion in New Mexico is typically grown on coarse soils with relatively low levels of organic matter compared with muck soils supporting onion production in the U.S. Midwest and Northeast. For soil-applied herbicides, soil organic matter influences rates effective for weed control, with effective rates generally increasing as levels of soil organic matter increase (Gonese and Weber, 1998). Accordingly, the rates for flumioxazin and oxyfluorfen in our study may not be suitable for seaside petunia control on muck soils or other soils with high levels of organic matter.

Low emergence after low-rate treatments of oxyfluorfen and flumioxazin should not be considered as evidence supporting field applications at belowlabel rates. This is because below-label rate applications may contribute to the development of herbicide-resistant biotypes in weed populations (Norsworthy et al., 2012). Also, below-label rates may not provide high levels of weed control in the field because preemergence herbicides can be more effective under greenhouse conditions than in the field (Zhao et al., 2017). Nonetheless, low emergence after below-label rate applications suggests that flumioxazin and oxyfluorfen control of seaside petunia is less influenced by processes that reduce amounts of herbicide available for plant absorption compared with the other preemergence herbicides evaluated in our study.

Foliar applications of bromoxynil, oxyfluorfen, and flumioxazin showed similar effectiveness on seaside petunia plants with stems 1 to $2 \mathrm{~cm}$ in length. However, for seaside petunia plants with stems 5 to $12 \mathrm{~cm}$ in length, the greatest reductions in seaside petunia biomass were caused by bromoxynil. Bromoxynil also caused total shoot death to seaside petunia plants with stems 5 to $12 \mathrm{~cm}$ in length, which was consistent with previous studies that indicated bromoxynil controlled weeds in the nightshade family, including hairy nightshade (Solanum physalifolium), eastern black nightshade (Solanum ptychanthum), and garden huckleberry (Solanum melanocerasium) (Eberlein et al., 1993; Zhou et al., 2006). Bromoxynil can be applied over the top of onions that have two to five true leaves (Winfield Solutions, 2016). Depending on crop planting date, the two- to five-leaf stage of onion coincides in part with the period of seaside petunia emergence, and thus bromoxynil is a candidate herbicide for controlling seaside petunia in onion.

Differences in seaside petunia control and biomass between bromoxynil and oxyfluorfen could have been caused in part by the application spray volumes. Postemergence herbicides in our study were applied using minimum spray volumes for onion indicated on product labels. This means bromoxynil was applied at $50 \mathrm{gal} / \mathrm{acre}$ (Winfield Solutions, 2016), and oxyfluorfen was applied at $20 \mathrm{gal} / \mathrm{acre}$ (Dow AgroScience, 2014). For herbicide applications directed to leaves, higher spray volumes increase the proportion of targeted foliage covered by the herbicide solution (Legleiter and Johnson, 2016) and potentially increase the efficacy of herbicides after foliar applications. A spray volume greater than $20 \mathrm{gal} / \mathrm{acre}$ may increase oxyfluorfen efficacy, although previous studies determined 

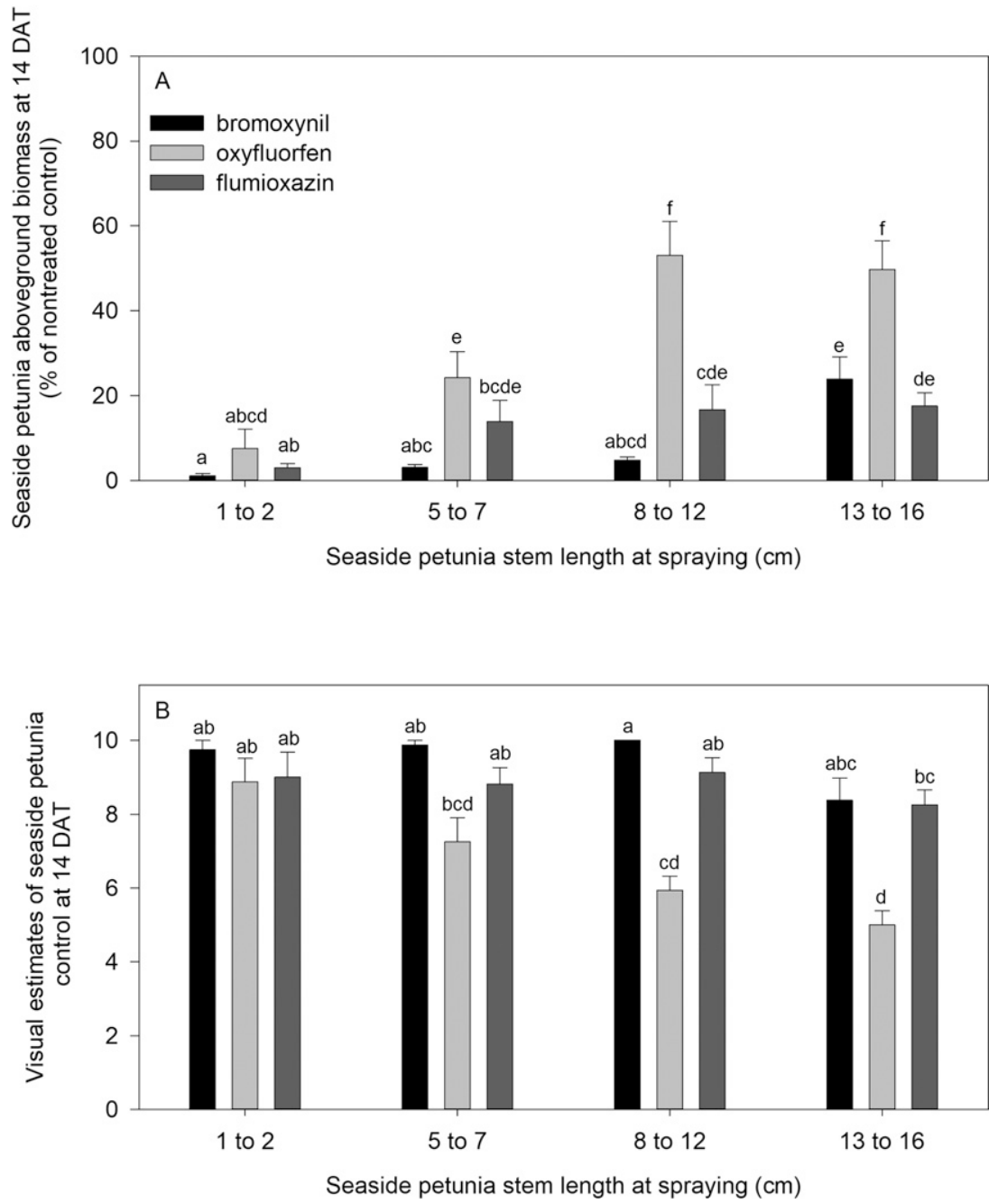

Fig. 4. (A) The effects of herbicide and plant size at spraying on aboveground biomass at $14 \mathrm{~d}$ after treatment (DAT) for seaside petunia plants grown in a greenhouse. (B) Visual estimates of seaside control at $14 \mathrm{DAT}$, with 0 indicating no injury and 10 representing shoot death. Herbicide treatments were bromoxynil at $0.37 \mathrm{lb} /$ acre, flumioxazin at $0.06 \mathrm{lb} /$ acre, and oxyfluorfen at 0.25 $\mathrm{lb} /$ acre with $0.25 \% \mathrm{v} / \mathrm{v}$ nonionic surfactant. Bars are means $( \pm \mathrm{SE})$ of eight replications from two pooled experimental runs. For a particular response variable, means with the same letter are not different at $P<0.05$ according to Tukey's test performed following arcsine transformation of the response variable. Data were back-transformed for presentation in this figure; $1 \mathrm{lb} /$ acre $=1.1209$ $\mathrm{kg} \cdot \mathrm{ha}^{-1}, 1 \mathrm{~cm}=0.3937$ inch.

that weed control outcomes from oxyfluorfen were not influenced (Schumacher and Hatterman-Valenti, 2007), or were minimally influenced (Zandstra and Wallace, 1989), by spray volume.

Another possible strategy for increasing seaside petunia susceptibility to foliar applications of oxyfluorfen is to apply an emulsifiable concentrate (EC) formulation of oxyfluorfen rather than the water-based suspension concentrate (SC) formulation used in our study, because a previous study determined that an EC formulation of oxyfluorfen improved control of specific broadleaf
Based on the results of our study, a promising herbicide program for seaside petunia in onion includes oxyfluorfen or flumioxazin for control of seaside petunia plants yet to emerge, and bromoxynil for control of seaside petunia plants that have already emerged. Future field trials should identify optimized application rates and application timings for controlling seaside petunia in onion with bromoxynil, flumioxazin, and oxyfluorfen. As herbicide recommendations are developed, additional research will be required to identify preventive measures and cultural practices to suppress population growth of this competitive weed.

\section{Literature cited}

Abrams, L. 1951. Illustrated flora of the pacific states. Vol. 3. Geraniums to figworts. Stanford University Press, Stanford, CA.

Beck, L. and J. Wanstall. 2021. Noxious and troublesome weeds of New Mexico. New Mexico State University, College of Agriculture, Consumer and Environmental Sciences, Las Cruces.

Borza, J.K., P.R. Westerman, and M. Liebman. 2007. Comparing estimates of seed viability in three foxtail (Setaria) species using the imbibed crush test with and without additional tetrazolium testing. Weed Technol. 21:518-522, https:// doi.org/10.1614/WT-06-110.

Dow AgroScience. 2014. GoalTender herbicide product label. EPA reg. no. 62719447. Dow AgroScience, Indianapolis, IN.

Eberlein, C.V., M.J. Guttieri, and F.N. Fletcher. 1993. Broadleaf weed control in potatoes (Solanum tuberosum) with postemergence directed herbicides. Weed Technol. 7:298-303, https://doi.org/ $10.1017 /$ S0890037X00027627.

Ekeleme, F., A. Dixon, G. Atser, S. Hauser, D. Chikoye, P.M. Olorunmaiye, A. Olojede, S. Korie, and S. Weller. 2020. Screening preemergence herbicides for weed control in cassava. Weed Technol. 34:735-747, https://doi.org/10.1017/ wet.2020.26.

Food and Agriculture Organization of the United Nations. 2021. Crops and livestock products, all countries, 2019 production quantity for onions, dry. 8 Aug. 2021. <http://www.fao.org/faostat/en/ \#data/QCL $>$.

Gilreath, J.P., B.M. Santos, P.R. Gilreath, and D.N. Maynard. 2008. Efficacy of early post-transplant herbicides in leeks (Allium porrum L.). Crop Prot. 27:847-850, https://doi.org/10.1016/ j.cropro.2007.06.005. 
Gonese, J.U. and J.B. Weber. 1998. Herbicide rate recommendations: Soil parameter equations vs. registered rate recommendations. Weed Technol. 12:235-242, https:// doi.org/10.1017/S0890037X00043748.

Grichar, W.J. 2007. Control of smellmelon (Cucumis melo) in soybean with herbicides. Weed Technol. 21:777-779, https:// doi.org/10.1614/wt-06-173.1.

Grichar, W.J., B.A. Besler, and K.D. Brewer. 2002. Citronmelon (Citrullus lanatus var. citroides) control in Texas peanut (Arachis hypogaea) using soilapplied herbicides. Weed Technol. 16:528-531, https://doi.org/10.1614/ $0890-037 \mathrm{x}$

(2002)016[0528:Cclvcc]2.0.Co;2.

Gunn, C.R. and F.B. Gaffney. 1974. Seed characteristics of 42 economically important species of Solanaceae. U.S. Dept. Agr., Agr. Res. Serv. Tech. Bul. 1471.

Herrmann, C.M., M.A. Goll, C.J. Phillippo, and B.H. Zandstra. 2017. Postemergence weed control in onion with bentazon, flumioxazin, and oxyfluorfen. Weed Technol. 31:279-290, https://doi.org/10.1017/ wet.2016.16.

Hutchinson, P.J.S. 2012. Common lambsquarters and hairy nightshade control in potato with dimethenamid-P alone and in tank mixtures and comparison of control by dimethenamid-P with $S$-metolachlor and metolachlor. Weed Technol. 26:279-283, https://doi.org/10.1614/ wt-d-10-00119.1.

Khamare, Y., S.C. Marble, N.S. Boyd, and S.T. Steed. 2020. PRE and POST control of Praxelis clematidea, an emerging weed in Florida nursery production. Weed Technol. 34:779-786, https:// doi.org/10.1017/wet.2020.53.

Kudsk, P. and J.L. Kristensen. 1992. Effect of environmental factors on herbicide performance, p. 173-183. In: Proceedings of the First International Weed Control Congress, Weed Science Society Victoria, Victoria, Australia.

Legleiter, T.R. and W.G. Johnson. 2016. Herbicide coverage in narrow row soybean as influenced by spray nozzle design and carrier volume. Crop Prot. 83:1-8, https:// doi.org/10.1016/j.cropro.2016.01.009.

Menges, R.M. and S. Tamez. 1981. Common sunflower (Helianthus annums) interference in onions (Allium cepa). Weed Sci. 29:641-647, https://doi.org/ $10.1017 / \mathrm{s} 0043174500040200$.

Nelson, E.A. and D. Penner. 2006. Enhancing herbicide selectivity with water-repellent adjuvants. Weed Technol. 20:677-681, https://doi.org/10.1614/ wt-05-10lr1.1.
Norsworthy, J.K., S.M. Ward, D.R. Shaw, R.S. Llewellyn, R.L. Nichols, T.M. Webster, K.W. Bradley, G. Frisvold, S.B. Powles, N.R. Burgos, W.W. Witt, and M. Barrett. 2012. Reducing the risks of herbicide resistance: Best management practices and recommendations. Weed Sci. 60:31-62, https:// doi.org/10.1614/ws-d-11-00155.1.

Qasem, J.R. 2007. Weed control in cauliflower (Brassica oleracea var. Botrytis L.) with herbicides. Crop Prot. 26:1013-1020, https://doi.org/10.1016/j.cropro.2006. 09.010

Richardson, R.J. and B.H. Zandstra. 2006. Evaluation of flumioxazin and other herbicides for weed control in gladiolus. Weed Technol. 20:394-398, https://doi.org/ 10.1614/wt-05-031r2.1.

Ritz, C., F. Baty, J.C. Streibig, and D. Gerhard. 2015. Dose-response analysis using R. PLoS One 10:e0146021, https:// doi.org/10.137/journal.pone.0146021.

Schumacher, C.E. and H.M. HattermanValenti. 2007. Effect of dose and spray volume on early-season broadleaved weed control in Allium using herbicides. Crop Prot. 26:1178-1185, https://doi.org/ 10.1016/j.cropro.2006.10.014.

Schutte, B.J. and E. Morris. 2019. Seaside petunia (Calibrachoa parviflora) effects on onion yield and responses to POST herbicides registered for dry bulb onion in New Mexico. 72nd Annu. Mtg Western Soc. Weed Sci. 72:17.

Taylor-Lovell, S., L.M. Wax, and G. Bollero. 2002. Preemergence flumioxazin and pendimethalin and postemergence herbicide systems for soybean (Glycine max). Weed Technol. 16:502-511, https:// doi.org/10.1614/0890-037x $(2002) 016$ [0502:Pfapap]2.0.Co;2.

Tei, F., A. Scaife, and D.P. Aikman. 1996. Growth of lettuce, onion, and red beet: 1 . Growth analysis, light interception, and radiation use efficiency. Ann. Bot. 78: 633-643, https://doi.org/10.1006/anbo. 1996.0171 .

U.S. Department of Agriculture, National Agricultural Statistics Service. 202la. Onions, dry: National acres planted. 8 Aug. 2021. <https://quickstats.nass. usda.gov/results/0C6B29F2-5BEE36DD-8B4A-344F29F6B15A>.

U.S. Department of Agriculture, National Agricultural Statistics Service. 2021b. Onions, dry: New Mexico acres harvested. 8 Aug. 2021. <https://quickstats.nass. usda.gov/results/9D0B760D-D9EA3876-A0D7-25584B0EEEB5>.

U.S. Department of Agriculture, National Agricultural Statistics Service. 2021c. Onions, dry: New Mexico production measured in cwt. 8 Aug. 2021. <https://quickstats.nass. usda.gov/results/5EC68EBl-A9F7-32349F04-60EBD4F8B922>.

U.S. Department of Agriculture, National Agricultural Statistics Service. 2021d. Onions, dry: State-level production measured in U.S. dollars. 8 Aug. 2021. $<$ https://quickstats.nass.usda.gov/results /CE034519-A685-32D2-80F7-6C64122 0DC9D $>$.

U.S. Department of Agriculture, National Agricultural Statistics Service. 2021e. Onions, dry, summer, non-storage production measured in cwt. 8 Aug. 2021. <https:// quickstats.nass.usda.gov/results/99ACCAC 5-D658-33E4-80A7-7823E74B2D60>.

U.S. Department of Agriculture, Natural Resources Conservation Service. 2021. PLANTS database for Calibrachoa parviflora (Juss.) D’Arcy, seaside petunia. 8 Aug. 2021. <https://plants.usda.gov/ core/profile?symbol=CAPA47 $>$.

Valent, U.S.A. 2019. Chateau herbicide SW product label. EPA reg. no. 5963999. Valent U.S.A., Walnut Creek, CA.

Walker, S., J. Ashigh, C. Cramer, T. Sammis, and B. Lewis. 2009. Bulb onion culture and management for southern New Mexico. New Mexico State Univ. Coop. Ext. Serv. Circ. 563.

Wicks, G.A., D.N. Johnston, D.S. Nuland, and E.J. Kinbacher. 1973. Competition between annual weeds and sweet spanish onions. Weed Sci. 21:436-439, https:// doi.org/10.1017/s0043174500027430.

Williams, M.M., C.V. Ransom, and W.M. Thompson. 2007. Volunteer potato density influences critical time of weed removal in bulb onion. Weed Technol. 21:136-140, https://doi.org/10.1614/ wt-06-009.1.

Winfield Solutions. 2016. Moxy 2E herbicide product label. EPA reg. no. 9779-346. Winfield Solutions, St. Paul, MN.

Wooten, E.O. and P.C. Standley. 1915. Flora of New Mexico. Contributions from the United States National Herbarium, Vol. 19. U.S. Govt. Printing Off., Washington, DC.

Zandstra, B.H. and T.F. Wallace. 1989. Postemergence weed control in onions (Allium cepa) with air-assisted, flat fan, and rotary nozzles. Weed Technol. 3:467-471, https://doi.org/10.1017/ S0890037X00032589.

Zar, J.H. 1999. Biostatistical analysis. 4th ed. Prentice-Hall, Upper Saddle River, NJ.

Zhao, L.X., M.J. Jiang, J.J. Hu, Y.L. Zou, Y. Cheng, T. Ren, S. Gao, Y. Fu, 
and F. Ye. 2020. Design, synthesis, and herbicidal activity of novel diphenyl ether derivatives containing fast degrading tetrahydrophthalimide. J. Agr. Food Chem. 68:3729-3741, https://doi.org/10.1021/ acs.jafc.0c00947.
Zhao, N., L. Zuo, W. Li, W. Guo, W. Liu, and J. Wang. 2017. Greenhouse and field evaluation of isoxaflutole for weed control in maize in China. Scientific Rpt. 7:12690, https://doi.org/10.1038/s41598-01712696-7.
Zhou, J.K., B. Tao, E.L. Deckard, and C.G. Messersmith. 2006. Garden huckleberry (Solanum melanocerasium) germination, seed survival, and response to herbicides. Weed Sci. 54:478-483, https://doi.org/ 10.1614/ws-05-096rl.1. 